\title{
ANSELM ON TRUTH AND GOODNESS
}

\author{
Anselmo sobre la verdad y el bien \\ Alice Ramos \\ St. John's University, Queens (New York)
}

\begin{abstract}
St. Anselm provides us with a metaphysics of the Logos, whereby things are true in relation to the Divine Intellect, or by the one first truth. This type of metaphysics has ethical implications, for the truth of man's essence needs to be brought to completion through right action. Rectitude of the rational creature's will is necessary for man's doing the truth or standing in the truth. This paper shows that the actualization of man's essence can only be achieved through the return of the rational creature to the Divine Truth, which is its exemplary and final cause.
\end{abstract}

Keywords: the Word, exemplar, truth, rational creature, image of God, rectitude of will, order.

\section{RESUMEN}

San Anselmo desarrolla una metafísica del Logos, mediante la cual las cosas son verdaderas por su relación con el Intelecto Divino, que es a su vez la primera Verdad. Esta metafísica tiene implicaciones éticas, ya que la verdad de la esencia de la criatura racional debe llegar a su plenitud a través de la acción recta. La rectitud de la voluntad es necesaria para que el hombre haga la verdad o se mantenga en la verdad. La actualización de la esencia del hombre sólo puede realizarse a través del retorno a la Verdad Divina, que es su causa ejemplar y causa final.

Palabras Clave: la Palabra Divina, ejemplar, verdad, criatura racional, imagen de Dios, rectitud de la voluntad, orden.

Some contemporary philosophers and theologians recognize the relevance of ancient and medieval thought to current metaphysical and ethical questions. While the AristotelianThomistic tradition is often invoked in such discussions, reference to St. Anselm of Canterbury and the Platonic tradition can also prove especially fruitful. ${ }^{1}$ In this paper we will consider first the question of the truth of creation. To speak of the truth or intelligibility of things is made possible in Anselm through the development of a metaphysics of the Logos, the type of metaphysics which relates things to the Divine Intellect.

It is interesting to note that the question of the Logos and of the intelligibility of things has been a topic of reflection in the works of the twentieth century theologians Romano Guardini and Joseph Ratzinger. In this introduction I would like to make mention of the

1 Working in the Aristotelian-Thomistic tradition in the area of ethics, one has only to think of the magisterial work of Alasdair MacIntyre. Perhaps less well known in the United States is the work of Josef Pieper whose books cover questions in metaphysics, ethics, and in other areas of philosophy as well, showing in a splendid way the contemporary relevance of Aquinas. 
Regensburg lecture given by Benedict XVI, now Pope Emeritus, in which he stressed the importance of the Logos, understood as reason and word, a reason which is creative and capable of communicating itself, precisely insofar as it is reason. ${ }^{2}$ In addition, the lecture insists that God acts with Logos and that it is contrary to the nature of God not to act according to reason. If God acts through the Logos when He creates, then all that is created is in fact intelligible and true. It may be said that the methodology of the sciences is based on the intelligibility of things, because modern scientific reason must accept as a given fact the rational structure of matter and the correspondence which exists between our mind and the rational structures of nature. ${ }^{3}$ A metaphysics of the Logos should thus be of particular interest to scientific reason since the latter accepts the intelligibility of things as a postulate for its task in the investigation of nature. Anselm's metaphysics can therefore open new vistas to the scientific mind, provided the scientist's reason is receptive to the light of faith and of grace. But, as we shall see, secondly in this paper, a metaphysics of the Logos also has ethical implications, for the Logos, which is the exemplary cause of things and thus measures the being and essence of things, is also the measure and norm of the finality of things. Anselm's metaphysical thought cannot therefore be dissociated from his ethical thought for having been created true, things must also act in accordance with the truth of their nature in order to return to their origin. A treatment of the truth of creation, as presented here, will thus make reference to the Neoplatonic circulation motif, or to the exitus-reditus theme, according to which every effect turns back by nature to the cause from which it originates. ${ }^{4}$ In this return to the origin the rational creature has a particular role to play.

Anselm conceived of creation as a copy or image of God. There is a form or likeness in the mind of God through which everything has been created and which is the supreme essence itself. While things were nothing before being made, as far as the reason of their maker is concerned, they were not nothing, for as Anselm says, «A maker makes something rationally if, and only if, there is already something there in his reasoning-as a sort of exemplar». ${ }^{5}$ The form that is in the maker's reason is, according to Anselm, a kind of verbalization of the thing to be created. To better understand this, Anselm uses the example of a craftsman, who before making something by means of his craft, expresses the thing within himself through a mental conception. ${ }^{6}$ Of course, the inner verbalization of the Creator and the mental conception of the craftsman are infinitely different. ${ }^{7}$ The analogy nonetheless is a good one as it helps to understand what otherwise would remain obscure to us. According to Anselm the expression of things in the reason of the Creator is in effect the Word, the Image of God or the Son, the Second Person of the Trinity. The Word through which God the Father says Himself is the Son and it is through this same Word that the Father says all creatures. Anselm insists that it is by

2 See Schall, J. V., The Regensburg Lecture, South Bend, Indiana, St. Augustine's Press, 2007.

3 Ibid.

4 See the excellent study on rectitude or right order by Pouchet, J. R., O.S.B., La rectitude chez saint Anselme: un itinéraire augustinien de l'âme à Dieu, Paris, Études augustiniennes, 1964; see also Rogers, K. A., The Neoplatonic Metaphysics and Epistemology of Anselm of Canterbury, Lewiston, New York, Edwin Mellen Press, 1997. In what follows of this article I will be making use of my previously published article, «Anselm on Truth», in the Proceedings of the American Catholic Philosophical Association, vol. 83 (2009), pp. 183-197. DOI:10.5840/acpaproc20098315.

5 Monologion IX. I am using the translations of Anselm's works found in B. Davies, and G. R. Evans (ed.), Anselm of Canterbury: The Major Works, Oxford, Oxford University Press, 1998. The word «reasoning» here is used to translate Anselm's ratio, which can also be rendered as reason.

6 Monologion X.

7 Monologion XI. 
«one and the same Word» that God says Himself and all that He makes. ${ }^{8}$ It may therefore be said that God expresses Himself in the Word and that the Word is the expression of the divine essence. ${ }^{9}$ Furthermore, the expression of the universe, of all creatures, is found in the Word. If we then consider creation as having its origin from the Word and as expressive of God, we will hold not only to the transcendence of the cause but also to a certain immanence of the cause in the effect. In the Word with which God says Himself every creature is expressed. ${ }^{10}$ Even before things are created, they exist according to Anselm in the Word, and are there original being and original truth, for they are what the Word is rather than what they are in themselves. ${ }^{11}$ Once made, however, creatures are «mutable essence, the product of immutable reason».12 And the more similar they are to the Word, to the «primary essence and the primary existential truth», the higher their degree of truth and excellence of existence. ${ }^{13}$

As creatures are but images and likenesses of God, of the simple and absolute essence, they are for Anselm but «pale imitations» of the creator. ${ }^{14}$ Because their existence is relational, that is, they exist in relation to the Word, it is only in and through the Word that they find their identity and completion. It is therefore only in relation to the Word that they will be perfected and will fully be what they are meant to be. The more similar creatures are to the Word, to the essence that exists supremely, the more excellent will they be. Anselm thus ranks creatures in such a way that living natures are above non-living, perceptive natures above non-perceptive, and rational natures above non-rational. According to Anselm, then, some natures may be said to exist more than others. For as he puts it, «A nature's comparative existence is the comparative similarity of its essence to the supreme essence, in just the same way as its comparative excellence is its comparative proximity, through its natural essence, to superlative excellence». ${ }^{15}$ While there is a multiplicity of perfections found in created beings such as existence, life, and rationality, all of these perfections exist in a participated way in creatures whereas in their source they are unlimited. For this reason, all the perfections or attributes of which Anselm speaks are wholly in God, not divided, for He is unity itself. ${ }^{16}$ Of the ranking of creatures that Anselm gives, clearly the rational creature is closest to the supreme essence since it understands, albeit in a limited way, as God Himself understands and speaks the Word. For Anselm, then, «every created nature stands at a higher stage of essence and worth the more it approximates to the Word». ${ }^{17}$

Now in speaking about things before they are created, Anselm tells us that all things are life and truth in the Word, as well as life and truth in God's knowledge. ${ }^{18}$ Since every creature exists paradigmatically in God, that is, according to an idea in God who is life, then the creature itself shares in that life of God. The Word contains in Himself the idea of each created being. The divine ideas are not however to be conceived of as a kind of model world, as something existing between God and His creatures, for these ideas are the very divine

8 Monologion XXXIII.

9 See Monologion XII.

10 See the introduction written by Soto Bruna, M. J., of St. Thomas Aquinas's De veritate 4, Pamplona, Cuadernos de Anuario Filosófico, Serie universitaria, 127 (2001), p. 27.

11 Monologion XXXIV.

12 Ibid.

13 Ibid.

14 Monologion XXXI.

15 Ibid.

16 Proslogion 18. In this section of the Proslogion, Anselm emphasizes the unity that exists in God: «Indeed You are unity itself not divisible by any mind. Life and wisdom and the other [attributes], then, are not parts of You, but all are one and each of them is wholly what You are and what all the others are».

17 Monologion XXXI.

18 Monologion XXXV. 
essence. The Word therefore is not an intermediary between God and creatures, but is rather God Himself. ${ }^{19}$ Not only are things life in the Word, but as Anselm emphasizes, they are also truth in the Word. How the Word knows and expresses things remains to a great degree incomprehensible to the human mind, just as human knowledge does not adequately grasp the essence of things. Our knowledge of things falls short of what things truly are in their essences, just as there is a great difference between how things are in the mind of the Creator, in the Word, and how they are in themselves, for created things exist in God according to an exemplary idea and not according to their singularity or individuality. In chapter XXXVI of the Monologion Anselm says, «For what created substances are in themselves is not what they are in our knowledge-a fact no one doubts. This is because in themselves they exist each through its own essence, whereas in our knowledge they exist as their likenesses, not their own essences. And it follows that they are more true in themselves than in our knowledge, just in proportion as they are more true through their own essence than through their likeness. And... they are more true in the Word (i.e., in the Creator's understanding) than in themselves, just in proportion as creative essence exists more truly than created essence. So then, how could the human mind comprehend the mode of saying and knowing of the supreme spirit? Our knowledge falls a long way short of created substances (by the gap between their essence and likeness), and they, in turn, fall so short of, and are so much less true than the saying and knowing of the supreme spirit». ${ }^{20}$ In this passage we find, then, that for Anselm things are more true in the Divine Word than they are in themselves, since it is only in relation to the Divine Truth that they are in effect true.

Anselm further explains what is meant by the truth of things in his De veritate, which provides us with a discussion of different types of truth. In the dialogue between the teacher and the student, the teacher says, «Whatever is, truly is, insofar as it is such as it is [...]. Therefore there is truth in the essence of all things, because it is by being in the highest truth that they exist [...]. If all things are what they are there, they are without doubt what they ought to be [...]. And whatever is what it ought to be, exists rightly». ${ }^{21}$ Anselm introduces here the interesting notions of «oughtness» and «rightness» and concludes that «if truth and rectitude are in the essence of things because they are that which they are in the highest truth, it is certain that the truth of things is rectitude». ${ }^{22}$ If things are more true and right in the Word, if they are what they are and ought to be in the highest Truth and Rectitude, then the relationship which exists between creatures and the Creator is a more intimate relationship than that which exists between an efficient cause and its effects. In Anselm the Creator is not only an efficient cause but also an exemplary and final cause. The Word, who is the exemplary cause, serves both to measure things in being and to measure them in activity-activity whereby creatures return to their original source..$^{23}$ It is then in the Word, in the exemplar, that the being and the truth of creatures have their origin and also their end. It is there that creatures have life. To situate in the Word, in the Creator's understanding, the foundation for the being and truth of things in no way denies the being of things in themselves. ${ }^{24}$

19 See Soto Bruna's introduction to Aquinas's question 4 of his De veritate, o.c., p. 26.

20 I am using the translation of the Monologion by Harrison, S., which appears in B. Davies, and, G. R. Evans (ed.), Anselm of Canterbury: The Major Works, o.c. I have however made some slight changes to the translation, as in the case where Harrison uses the adjective «authentic» rather than «true».

21 De veritate VII. Emphasis is mine, as I wish to underline the fact that Anselm is speaking about how things are in the highest truth which is the Word.

22 Ibid.

23 Pouchet, J. R., o.c., p. 67.

24 See Soto Bruna's introduction to Aquinas's question 4 of his De veritate, o.c., p. 26. 
Given that created things are copies or likenesses of their origin, of the Word who is their exemplary cause, we might say that there is found impressed on them an idea which accounts for their intelligibility and truth and which makes them expressive of their Creator. It is therefore through visible things that are intelligible and true that the human mind can rise to knowledge of the invisible Truth. The mind's journey to God through visible things that are traces or images of God in the universe is described by Anselm when he makes reference to the following verses from St. Paul: «We see now through a mirror in an obscure manner, but then face to face. Now I know in part, but then I shall know even as I have been known». ${ }^{25}$ Only through the essence of things which reflect the divine essence itself can we come to know something of what we desire to see and know fully. And that desire in the human mind is made possible through the imprint, as it were, of the Word who is both the exemplary and final cause of creatures.

It is through the creature that resembles the Creator more that we acquire ever more adequate knowledge of God. According to Anselm, the natural essence of the rational mind resembles most the supreme essence and can thus help us in the task of inquiring as to the supreme nature. The best way therefore to acquire knowledge of God is by turning to the human mind. Anselm even says that «insofar as [the rational mind] forgets to look at itself, it falls from its reflection on the supreme nature». ${ }^{26}$ The rational mind is for Anselm, as it was for Augustine before him, both an image and a mirror of God. As Anselm says, «The mind, therefore, might be most appropriately called its own mirror. The mirror in which it sees the reflection of that which... it cannot see 'face to face'. For if the mind, alone of all created things, can love, understand and be conscious of itself, I do not see why one should say that it is not the true image of that essence which, in its love, understanding, and consciousness of itself, constitutes an ineffable threeness». ${ }^{27}$ The rational mind is then the image of the divine essence, of the triune God professed by Anselm. Since there is no object more intelligible and lovable than God, the more the human mind understands and loves God, the better will it reflect and mirror God and thus the better and more truly will it be an image of God. Giving expression to what Anselm calls «this impressed image», that is, the image of God as it exists in man, constitutes the actualization of the mind's potential, which can only be brought about through an act of the will. ${ }^{28}$ Striving to actualize itself in this way, to express God, is «the debt that rational creation owes its Creator. A debt above and beyond the fact that it exists». ${ }^{29}$ Thus for Anselm the rational mind has a debt toward its Creator which it can only satisfy by knowing and loving the Creator who is the supreme good. Because of the excellence of this activity, Anselm concludes that «the more we ought to want to do it». ${ }^{30}$ The debt that the rational mind has with its maker is precisely that for which the mind was made and so in satisfying the debt the mind is merely doing what it ought to do, what is in fact the right or the true thing to do.

According to Anselm the rational mind has the capacity to discern and judge the difference between the true and the untrue, the good and the not good, the just and the unjust. Rational existence has been made in such a way that it is able to judge what is or is not in

251 Cor. 13: 12. In Monologion LXX Anselm only gives part of the verse. I have wanted to quote it in its entirety for its importance to what will follow in my exposition.

26 Monologion LXVI.

27 Monologion LXVII.

28 Monologion LXVIII.

29 Ibid.

30 Ibid. 
harmony with the mind and to love or spurn the object judged. Since the supreme essence is maximally true, good, and just, the rational creature is made to love it. The purpose of the rational creature is thus «to love the supreme essence and only to love other things for the sake of the supreme essence». ${ }^{31}$ Since other good things are simply traces or faint imitations of the Word, they are really nothing in comparison to the Word who is the one true good. The supreme essence is then that which alone the mind should take joy in. If the rational creature desires and loves the supreme essence in the way it ought, that is, for the sake of the supreme essence itself, then the rational creature will one day behold that face which it now only sees faintly, as through a mirror. It will enjoy supreme happiness and will live the happy life forever, which is life in God. ${ }^{32}$

As Anselm maintains, to delight rightly in things is to delight in them for the sake of the supreme essence since it is precisely the supreme essence that is «the good above all other things». ${ }^{33}$ The good man who does this throughout his earthly life will experience the «fullness of joy» in the next life. ${ }^{34}$ As is his custom, Anselm cites a key Scriptural text regarding the judgment of souls who are commended for having done well and are invited to «enter into the joy of the Lord». ${ }^{35}$ Even though Anselm does not cite the text in its entirety, it is interesting to note here that the souls who are fit to enter into the joy of the Master are precisely those that are commended for having been «good and faithful servants», that is, the servants who did their duty. ${ }^{36}$ In other words, they did as they ought to have done, they did the right or true thing. The just servants are thus approved by the Master who is also their Judge and rewarded for the fulfillment of their duty.

By contrast, the foolish and slothful servants will be reproved by the Master and punished for the evasion of what they knew to be right and just. These foolish and unwise servants are not known or recognized by the Master ${ }^{37}$ because they have not done what they ought to have done, and so they have not conformed themselves to the original idea and the original truth in their maker's mind. There is then no adaequatio between the creature and the Divine Intellect and so truth is lacking. ${ }^{38}$ The measure or norm of our finality, like the measure of our being and essence, resides in the exemplary idea according to which we were created, that idea which is none other than the divine essence, the Word. The foolish servants are not only deprived of entering into the joy of the next life, but also and more importantly of seeing the Master. They are thus deprived of seeing and enjoying what they were made to contemplate and love. Man's natural desire to know the truth, his desire to see God «face to face» and thus to know the divine essence, can therefore be frustrated because man distances himself from the truth and thus does not stand in the truth. For Anselm sin consists precisely in not standing in the truth. In fact, sin makes us unlike the Word, unlike our original truth. As Anselm puts it, «For those presuming a false likeness to God seem to have sinned more particularly against Him whom we profess to be the true likeness of the Father». ${ }^{39}$

31 Ibid.

32 Monologion LXX-LXXIV.

33 Monologion LXVIII.

34 Proslogion XXVI.

35 Ibid. Anselm refers to Matt. 25:21 in chapter XXVI of the Proslogion.

36 Matt. 25:21.

37 We might cite here-although Anselm himself does not do so-the parable of the foolish maidens who are not given entry into the marriage feast and who are not recognized or known by the bridegroom, in Matt. 25:12.

38 See Pouchet, J. R., o.c., p. 67.

39 On the Incarnation of the Word, chap. X. 
Moreover, Anselm's reference to the following Scriptural verses, which I quoted above regarding the mind's ascent to God, seem of particular relevance here: «We see now through a mirror in an obscure manner, but then face to face. Now I know in part, but then I shall know even as I have been known». ${ }^{40} \mathrm{I}$ take this to mean that we will know, just as the wise and unwise servants knew, if we have been approved or not, if we can in effect «enter into the joy of the Lord». ${ }^{41}$ If through the face we have knowledge of the person, ${ }^{42}$ and if the cause of things is God's knowledge of approbation, ${ }^{43}$ then the end of the rational creature on seeing God's face will be, as it were, to enter into God's knowledge of approbation or of reprobation, and thus to experience inexplicable joy or eternal unhappiness. The Divine Face will thus confer on some souls true commendation and glory, and on others dishonor and shame, ${ }^{44}$ for they have not satisfied their debt of giving honor to God.

According to Anselm and the Scriptural passages that he cites, the souls that will see and rejoice will be the ones who are «right of heart», or simply right in will. ${ }^{45}$ The rightness or rectitude of the will which is preserved for the sake of rectitude itself is what Anselm calls justice. Since for Anselm «all truth is rectitude», ${ }^{46}$ «a rectitude perceptible by the mind alone», ${ }^{47}$ then justice which is a rectitude of will also involves truth. As Anselm says, «Truth, rectitude, and justice mutually define one another». ${ }^{48}$ The man, who does what he ought, acts with rectitude and does the truth. When man willingly does what he ought to do, he is called just. Praise or blame is given to the just man, not to the creature who does not know rectitude and can therefore not willingly do what it ought. The just man, however, not only wills what he ought but also wills rectitude for its own sake. He does not will the right thing because he is forced to do it or because he seeks his own glory. In preserving rectitude for its own sake, the just man can be said to preserve the truth or to do the truth, for in this way we are reuniting ourselves to the creative act whereby God made the human will right, that is, oriented to what it ought to do. ${ }^{49}$ Only by being just, by having rectitude of will, can we really do the truth. Doing the truth, having truth in the will, enables us to «come into the light», ${ }^{50}$ and thus to be

401 Cor. 13:12. See note 25 above.

41 See note 33.

42 See ST II-II, q. 180, a. 5, ad 1, where Aquinas cites the following words from St. Gregory: «Since we know a man by his face, by the face of God [Jacob] signified his knowledge of Him», in Moral. XXIV, 6.

43 A text which is particularly relevant here is $S T$ I, q. 14, a. 8, resp., where Aquinas says, «Now it is manifest that God causes things by His intellect, since His being is His act of understanding, and so His knowledge must be the cause of things, in so far as His will is joined to it. Hence the knowledge of God as the cause of things is usually called the knowledge of approbation».

44 See what I say regarding glory and shame in my article, «The Dignity of Man and Human Action», in Acta Philosophica, 10.2 (2001), pp. 315-321. See also my book, Dynamic Transcendentals: Truth, Goodness, and Beauty From a Thomistic Perspective, Washington, D.C., The Catholic University of America Press, 2012, pp. 108-132.

45 See De veritate XII, where Anselm describes those who are just as «right of heart» or «right of will». He also cites Psalm 31:11 and Ps. 106:42.

46 Ibid.

47 De veritate XI.

48 De veritate XII.

49 On the Fall of the Devil IX. In this text Anselm says the following: «As long as the will originally given to a rational nature is simultaneously oriented to its rectitude by the same act with which God gives it, thus not only inclined to rectitude, but created right, that is, oriented to what it ought to do, as long as, I say, the will remains in that rectitude that we call truth or justice, it was just. But when it distanced itself from what it ought and turned against it, it did not remain in the original rectitude in which it was created».

50 De veritate V. 
in accord with the highest truth. ${ }^{51}$ It is evident therefore that it is not sufficient for the rational creature to have been created true, for the truth of his essence needs to be brought to completion through right action.

To have access to the fullness of light and of truth can only be achieved by a will that subjects itself to God, and thus recognizes, as it were, that it does not belong to itself, that it is not its own. The creature, as Anselm so often reminds us, is nothing in comparison to God who is self-sufficient; the sufficiency of the creature lies in God. Anselm contrasts the will of the human being to the will of God when he says, «A will subject to no one else's is one's own. But possessing a will as one's own (i.e., a will subject to no will) belongs to God alone. Therefore, all who exercise their will as their own strive to be like God by robbery and are guilty of depriving God of the dignity proper to Him and of His unique excellence, insofar as it lies within their power to do so». ${ }^{52}$ When the rational creature wishes to make himself «like God by robbery», he acts falsely and unjustly. Since, as Anselm points out, the Son of God, the Word, who is «the splendor of eternal light and the true image of the Father», ${ }^{53}$ humbled Himself and submitted His will to the will of the Father, the rational creature's sins put him especially at odds with the Word, with his exemplar, who is also the highest truth. We might also say that the rational creature's sins put him at odds with himself, with his original truth and place in the universe. In addition, his sins put him at odds with the order of the universe as designed and willed by Divine Wisdom.

The rational creature has not only the capacity to understand what is right but also the capacity to desire what is right. In doing what is right, true, and just for the sake of rectitude itself, the rational being is acting, according to Anselm, in consonance with the order of the universe, whereas when he does what is wrong, false, and unjust he brings about disorder. In this regard, Anselm says, «When... [a rational being] desires what is right, he is honoring God, not because he is bestowing anything upon God, but because he is voluntarily subordinating himself to His will and governance, maintaining his own proper station in life within the natural universe, and, to the best of his ability, maintaining the beauty of the universe itself. But when a rational being does not wish for what is right, he dishonors God, with regard to himself, since he is not willingly subordinating himself to God's governance, and is disturbing, as far as he is able, the order and beauty of the universe». ${ }^{54}$ While it is the case for Anselm and for other medieval thinkers that sin disrupts the order of the universe and its beauty, this order is made right again by God who exacts voluntary recompense for wrongdoing or inflicts punishment on hardened hearts. In this way God's order is imposed on wrongdoers. Rational creatures cannot therefore flee from the order of Divine Wisdom nor escape from the subjection to the Divine Will. According to Anselm, if the Divine Wisdom did not impose any form of satisfaction for sin or punishment in cases where wrongdoers were attempting to disrupt the right order of things, there would then be in the universe a certain ugliness, which would result from the violation of the beauty of order, and God would thus appear to be failing in His wise governance of the world. It would seem therefore that when the rational creature does the truth, when he has justice in his will, by ordering his lower powers to the rational mind and the mind to God, he then not only honors God and preserves his own dignity but also contributes to the order and beauty of the universe, whereas when the

51 De veritate XIII. Anselm says, «So the highest truth subsists in itself and belongs to no thing. But when something is in accord with it, we then speak of its truth and rectitude».

52 On the Incarnation of the Word X.

53 Ibid.

54 Why God Became Man Book I, chap. XV. 
rational creature willingly abandons justice, such an action constitutes personal dishonor and debasement, ${ }^{55}$ because it alienates him from the Divine Mind, from the highest truth.

Because of the loss of original justice Anselm reminds us that rational creatures are in a state of internal division, as it were. He quotes Scriptural verses to the effect that «the flesh... lusts against the spirit», and the «law of sin which is in our members, fights against the law of the mind». ${ }^{56}$ Injustice is not, according to Anselm, in the essence of the sensible appetites but rather in the rational will that follows them. When the will resists the disordered movements of the appetites, then the will is just, delighting, as Anselm says with words of St. Paul, «in the law of God according to the inner man». ${ }^{57}$ The justice, the rectitude, or the truth commanded by the law is the law of God in so far as it originates in God, but it is also the law of the mind in so far as the mind understands the law. ${ }^{58}$ The mind or the inner man thus has access to the law of God given by Divine Reason. The mind partakes, so to speak, of Divine Reason, and it is this share, I think, which drives the desire to see and to know God. In the Proslogion where Anselm seeks to see the countenance of God and to access God's inaccessible light, it can be said that such a desire is the result of the imprint of the Divine Light on the rational mind. It is precisely by this imprint or participation in the divine light, whereby the Word speaks within us, that we can know the good and direct ourselves to the one true good. However, because of the division that exists in man due to both original sin and his own personal sins, his participation in the divine light, the impressed image of God within him, has been disfigured and needs to be reformed or recreated.

Without entering here into the reasons why God became man in order to effect man's salvation, in order to liberate him from sin, and unite him to Himself, we can say that natural reason weakened by sin needs the light of faith and of grace. As Anselm tells us so often, faith is necessary for understanding. The power of reason in the soul which ought to be «the ruler and judge of everything» in the human person finds itself caught up in «material fancies» such that it cannot rise from these to the spiritual. ${ }^{59}$ Therefore, the human heart needs to be cleansed by faith, and the eyes need to be illumined by the observance of God's commandments. ${ }^{60}$ For Anselm, as for other Christian thinkers, human wisdom is not sufficient for understanding. We need to have recourse to the Word of Wisdom which requires the humble submission of the human mind. Anselm says, «And we ought to become little ones by humbly obeying the testimonies of God, so that we learn the wisdom that 'the trustworthy testimony of the Lord, manifesting wisdom to the little ones' [Ps. 19: 7], gives». ${ }^{61}$ If we accept the Word of Wisdom, then we will, according to Anselm, live according to the spirit, and no longer according to the flesh by which we are carnal and animal. ${ }^{62}$ We will no longer then live in darkness. We will participate more fully in that light which will enable us to judge everything rightly and be judged by no one. ${ }^{63}$ It might be said that those who truly accept and understand the Word of Wisdom, the Exemplar, also love it, and thus more intensely desire union with the Word, desire to see His Face.

55 On the Fall of the Devil XVI.

56 Virgin Conception and Original Sin IV.

57 Ibid.

58 Ibid.

59 On the Incarnation of the Word $\mathrm{I}$.

60 Ibid. Anselm is quoting from Scripture: Acts 15:9 and Ps. 19:7.

61 Ibid.

62 Ibid

63 Ibid. Anselm quotes the following Scriptural verse: «Spiritual persons judge everything, and they are themselves judged by no one», in 1 Cor. 2:15. 
The knowledge that is most fitting to us, to those with minds and hearts, is an affective knowledge, and it is for this reason that I think Anselm says, «Those who have not believed will not understand. For those who have not believed will not find by experience, and those who have not found by experience will not know. For example, the more experience transcends hearing about things, the more the knowledge of those experiencing things surpasses the knowledge of those hearing about them». ${ }^{64}$ Knowledge alone is not sufficient; there must be a sort of connaturality between man and the true good, a connaturality which is rooted in and developed through the virtuous attitudes of the person himself. The mind and its activity therefore need an ordering of the heart's loves. It is not surprising then that Anselm should speak of the importance of virtues such as humility and obedience, virtues that enable us to submit our mind and heart to God, and thereby to become spiritual, judging rightly, with wisdom, and becoming the measure and rule of human acts, ${ }^{65}$ and thus more like the Exemplar, the highest truth, the ultimate measure.

The understanding of divine things then requires faith, virtue, and wisdom. In addition, Anselm seems to hold to a kind of instinctive awareness of God and goodness. Given the presence of the impressed image of God in the rational creature and the intelligibility of creation itself, men do have the means of knowing God. They can, if they will, recognize the power and grandeur of God as these are revealed in the created world. But instead, captivated by the sensible beauty of creatures they turn to what is inferior in dignity, idolizing them and thus not recognizing in them images of their maker. ${ }^{66}$ And so for Anselm only the fool could say in his heart that God does not exist. The fool whose sense of judging has been dulled by being plunged into earthly things is not capable of perceiving divine things. Instead of giving expression to the impressed image of God within, the fool's denial of God, unlike the spiritual man's acceptance of Divine Wisdom, has deep moral and intellectual consequences. Only the spiritual man can then give expression to the impressed image of God within him, and so actualize his essence and become more like the Word. It is in this way also that the spiritual man, who knows now in part, will know even as he has been known.

To return then to my introductory remarks, it seems that while the truth of things is certainly important, the rational creature's becoming adequate to the Divine Intellect, reuniting itself to the Exemplar, who contains or is the truth of each rational creature, is of vital importance. For in this adaequatio will lie its happiness or unhappiness, the satisfaction of its desire to see God «face to face», or the alienation from its true good. Moreover, for the scientist whose reason is open to the light of faith, Anselm's metaphysics of the Logos can certainly provide an enriched understanding of the universe and of human life.

Fecha de recepción: día 25 de junio 2014

ramosa@stjohns.edu

Fecha de aceptación: día 9 de septiembre de 2014

64 Ibid.

65 See ST I, q. 1, a. 6, ad 3. In this response Aquinas speaks of a twofold manner of judging and of a twofold wisdom, since judgment pertains to wisdom.

66 See chapter 10 of the Book of Wisdom. 